Terbit online pada laman : http://teknosi.fti.unand.ac.id/

Jurnal Nasional Teknologi dan Sistem Informasi

ISSN (Print) 2460-3465 | ISSN (Online) 2476-8812

Studi Kasus

\title{
Penerapan Aplikasi Berbasis Web Untuk Monitoring Pengobatan Pasien Gangguan Jiwa Pada UPT Puskesmas Pasar Usang
}

\author{
Ricky Akbar ${ }^{a}$, Fajril Akbar ${ }^{b}$, Wardatul Alifah $^{c}$ \\ ${ }^{a, b, c}$ Jurusan Sistem Informasi, Universitas Andalas, Kampus Limau Manis, Padang 25163, Indonesia
}

\section{INFORMASI ARTIKEL}

Sejarah Artikel:

Diterima Redaksi: 06 November 2020

Revisi Akhir: 21 Desember 2021

Diterbitkan Online: 31 Desember 2021

\section{KATA KUNCI}

Monitoring Pengobatan Pasien,

Aplikasi Web,

UPT Puskesmas Pasar Usang

KORESPONDENSI

E-mail: rickyakbar@it.unand.ac.id

\section{A B S T R A C T}

Monitoring pengobatan pasien gangguan jiwa adalah pemantauan yang dilakukan oleh pemegang program kesehatan jiwa terhadap pelaksanaan prosedur pengobatan yang dilakukan oleh pasiennya. Selama ini proses pelaksanaan kegiatan monitoring pengobatan pasien gangguan jiwa pada Unit Pelaksana Teknis (UPT) Puskesmas Pasar Usang, Dinas Kesehatan Kabupaten Padang Pariaman belum berjalan dengan baik karena faktor pengelolaan data pasien yang masih dilakukan secara manual. Hal ini menyebabkan penanggung jawab program kesehatan jiwa kesulitan dalam mencari data pasien gangguan jiwa dan tidak memperoleh informasi tentang jadwal kunjungan berobat pasiennya. Selain itu susahnya mengetahui pasien-pasien yang tidak melakukan proses pengobatan secara teratur ke puskesmas (pasien home visit). Sehingga dapat mengakibatkan semakin tingginya tingkat kekambuhan penyakit pasien gangguan jiwa pada UPT Puskesmas Pasar Usang. Maka salah satu solusi untuk mengatasi permasalahan tersebut adalah dengan membangun dan menerapkan sebuah aplikasi untuk dapat melakukan monitoring pengobatan pasien gangguan jiwa. Metodologi penelitian yang digunakan adalah studi literatur sebagai landasan teori dari data penelitian sebelumnya, pengumpulan data berupa observasi, wawancara dan pengumpulan dokumen. Sementara itu metodologi yang digunakan untuk pengembangan aplikasi adalah Waterfall dengan tahapan requirements definitions, system and software design, implementation, dan system testing. Dengan diterapkannya Aplikasi monitoring pengobatan pasien gangguan jiwa berbasis web ini, maka proses monitoring yang berjalan di puskesmas dapat berjalan lebih baik dari sebelumnya.

\section{PENDAHULUAN}

Unit Pelaksana Teknis Pusat Kesehatan Masyarakat (UPT Puskesmas) Pasar Usang adalah sebuah lembaga atau kesatuan organisasi kesehatan fungsional yang berada di bawah naungan Dinas Kesehatan Kabupaten Padang Pariaman yang bertugas untuk menyelenggarakan upaya kesehatan kepada masyarakat di sekitar daerah operasionalnya [1]. Salah upaya kesehatan yang dilakukan adalah program kesehatan jiwa. Yang bertujuan agar penderita gangguan kesehatan jiwa lebih cepat ditangani dan mendapat pengobatan yang sesuai.

Gangguan jiwa adalah suatu perubahan pada fungsi jiwa yang menyebabkan adanya gangguan pada fungsi jiwa yang menimbulkan penderitaan pada individu dan hambatan alam melaksanakan peran sosial [2]. Gangguan jiwa mengakibatkan penderitanya tidak bisa menerima fakta serta tidak bisa menahan dirinya untuk mengganggu orang-orang disekitarnya atau menyakiti dirinya sendiri [3]. Penderita gangguan jiwa ini sewaktu-waktu dapat mengalami kekambuhan. Kekambuhan penyakit gangguan jiwa dapat disebabkan oleh beberapa faktor seperti ketidakpatuhan penderita dalam meminum obat, tidak melakukan kontrol ke dokter secara teratur, berhenti minum obat tanpa disetujui dokter, kurangnya support dan perhatian dari keluarga penderita, serta munculnya masalah baru yang menambah beban penderita sehingga penderita kambuh dan perlu dirawat di rumah sakit [4].

Salah satu program kesehatan jiwa sesuai dengan peraturan Departemen Kesehatan adalah untuk memantau pengobatan pasien guna menghindari kekambuhan penyakit yang semakin parah. Pada tahun 2018, UPT Puskesmas Pasar Usang melayani 101 pasien penderita gangguan jiwa [5]. Salah satu bentuk pelayanan yang dilakukan oleh penanggung jawab program kesehatan jiwa yaitu monitoring pengobatan pasien gangguan jiwa. Monitoring pengobatan pasien gangguan jiwa adalah pemantauan yang dilakukan oleh pemegang program kesehatan jiwa terhadap pelaksanaan prosedur pengobatan yang dilakukan oleh pasiennya. Proses monitoring ini dilakukan untuk menekan 
angka kekambuhan penyakit pasien gangguan jiwa. Bentuk kegiatan monitoring yang dilakukan adalah memantau kunjungan pasien gangguan jiwa atau keluarga pasien ke puskesmas untuk melakukan pemeriksaan dan pengambilan obat serta mengunjungi rumah pasien gangguan jiwa yang tidak patuh dalam melakukan pengobatan. Monitoring pengobatan pasien gangguan jiwa dilakukan berdasarkan data riwayat kunjungan berobat pasien gangguan jiwa yang dicatat dan disimpan dalam buku register poliklinik umum .

Selama ini proses monitoring yang dilakukan oleh penanggung jawab program kesehatan jiwa UPT Puskesmas Pasar Usang, tidak berjalan dengan maksimal. Penanggung jawab program kesehatan jiwa kesulitan dalam mencari data pasien gangguan jiwa dan tidak memperoleh informasi tentang jadwal kunjungan berobat pasien. Selain itu juga tidak mengetahui pasien-pasien yang tidak melakukan proses pengobatan secara teratur ke puskesmas (pasien home visit) yang mengakibatkan semakin tingginya tingkat kekambuhan penyakit pasien gangguan jiwa pada UPT Puskesmas Pasar Usang. Hal ini disebabkan oleh data riwayat pengobatan pasien gangguan jiwa tidak tersaji dengan baik karena masih disimpan secara manual di dalam buku register dan tergabung dengan data pasien lainnya.

Dari permasalahan yang terjadi pada UPT Puskesmas Pasar Usang, maka salah satu solusi yang dapat dilakukan adalah dengan melakukan penerapan sebuah aplikasi monitoring pengobatan pasien gangguan jiwa yang dapat menyimpan datadata pasien dan riwayat kunjungan berobatnya secara terpusat. Aplikasi ini dapat menyajikan informasi yang dibutuhkan oleh penanggung jawab program kesehatan jiwa untuk melakukan monitoring pengobatan pasien gangguan jiwa pada UPT Puskesmas Pasar Usang dan menghasilkan notifikasi untuk melakukan home visit ke rumah pasien yang tidak teratur dalam melakukan pengobatan.

Dalam membangun aplikasi ini dibutuhkan tools untuk melakukan pemodelan dari sistem yang ada, antara lain menggunakan Business Process Modelling Notation (BPMN), yaitu alat yang digunakan untuk memodelkan proses bisnis dengan menggunakan notasi yang mudah dipahami penggunanya, termasuk juga analisis bisnis untuk menciptakan draft awal dari proses sampai pengembang teknis menerapkan teknologi yang digunakan untuk menjalankan proses-proses tersebut [6]. Selain itu, aplikasi ini juga membutuhkan metode dalam pengembangan system yaitu Unified Modelling Language (UML), adalah suatu metode untuk mengembangkan system dengan menggunakan bahasa grafis untuk mendokumentasikan dan melakukan spesifikasi pada system [7]. UML yang digunakan untuk membangun aplikasi ini antara lain use case diagram, use case scenario, sequence diagram dan class diagram.

Use case diagram digunakan untuk mendeskripsikan logika dan fungsional suatu software [8]. Use case scenario merupakan penjabaran dari masing-masing use case dalam bentuk uraian nama aktor yang berhubungan dengan use case, tujuan, deskripsi global, pra-kondisi yang harus dipenuhi, dan pascakondisi yang diharapkan setelah berjalannya fungsional use case [9]. Sementara itu sequence diagram menjelaskan bagaimana tahapan dalam melakukan suatu alur proses, bagaimana suatu proses itu dilakukan, pesan apa yang dikirim dan diterima, serta penempatan diagram berdasarkan waktu pelaksaan prosesnya [10]. Dan Class Diagram adalah tahapan dalam menggambarkan struktur kelas-kelas dari suatu system [11].

\section{METODE}

Pada penelitian ini digunakan metode pengumpulan data dan metode pembangunan aplikasi. Metode pengumpulan data dilakukan dengan studi lapangan dan studi literatur, dimana studi lapangan terdiri dari observasi, wawancara, dan analisis dokumen. Untuk metode pembangunan aplikasi menggunakan metode waterfall. Waterfall adalah metode pengembangan aplikasi yang terstruktur karena dilakukan secara pertahap. Tahap sebelumnya harus dilengkapi terlebih dahulu sebelum mengerjakan tahap selanjutnya [12]. Metode pengembangan dengan model waterfall dapat dilihat pada gambar 1 .

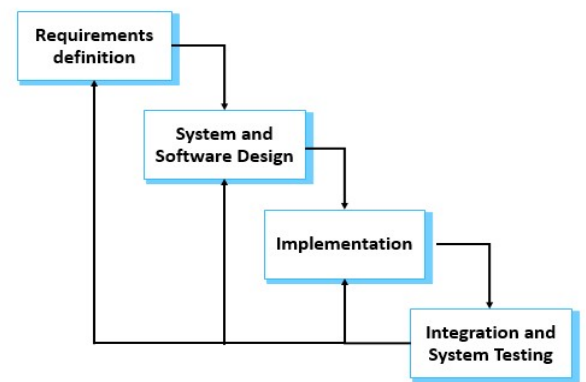

Gambar 1. Metode Waterfall [12]

Berdasarkan gambar 1 dapat dijelaskan tahapan-tahapan metode pengembangan aplikasi yang digunakan yaitu:

1. Requirement Analysis and Definition

Pada tahapan ini dilakukan proses pengumpulan data yang terkait dengan dokumen yang digunakan dalam kegiatan pendataan laporan hingga pengamatan langsung proses pengobatan pasien gangguan jiwa pada UPT Puskesmas Pasar Usang.

2. System and Software Design

Dalam tahapan ini dibentuk suatu arsitektur sistem berdasarkan persyaratan yang telah ditetapkan pada tahapan sebelumnya. Pemodelan sistem dilakukan dengan membuat proses alur sistem pengobatan yang diusulkan menggunakan tools BPMN dan diagram UML (use case diagram, use case scenario, sequence diagram dan class analysis). Untuk software design terdiri dari perancangan Entity Relationship Diagram (ERD), arsitektur aplikasi dan user interface aplikasi

3. Implementation

Dalam tahapan ini, hasil dari desain perangkat lunak akan direalisasikan sebagai satu set program atau unit program. Pengimplementasian hasil desain perangkat lunak kedalam bahasa pemrograman menggunakan bahasa pemrograman PHP dengan berorientasi pada objek.

4. Integration and System Testing

Dalam tahapan ini, setiap unit program yang telah dibentuk sehingga memenuhi fungsional yang diharapkan akan diintegrasikan satu sama lain dan diuji sebagai satu sistem yang utuh untuk memastikan sistem sudah memenuhi persyaratan yang ada. Pengujian sistem ini dilakukan dengan metode black box testing yaitu dengan cara melakukan pengujian berdasarkan 
fungsional sistem apakah telah sesuai dengan yang diharapkan atau belum [13].

\section{HASIL}

\subsection{Analisis Sistem}

Tahapan analisis sistem menjelaskan tentang sistem yang sedang berjalan dan sistem yang diusulkan yang dimodelkan dengan menggunakan tools Business Process Modelling Notation (BPMN). Sedangkan untuk membuat pemodelan system menggunakan Unified Modelling Language (UML). UML yang digunakan dalam pemodelan sistem ini adalah use case diagram, use case scenario, sequence diagram, dan class analysis.

\subsubsection{Sistem yang Berjalan}

Proses-proses bisnis yang berjalan pada UPT Puskesmas Pasar Usang saat ini meliputi: kunjungan pasien gangguan jiwa pada poliklinik umum, monitoring pengobatan pasien gangguan jiwa dan pengambilan obat pasien gangguan jiwa. Untuk penelitian ini diambil salah satu proses bisnis yang berjalan yaitu Alur proses monitoring pengobatan pasien gangguan jiwa yang dapat dilihat pada Gambar 2.

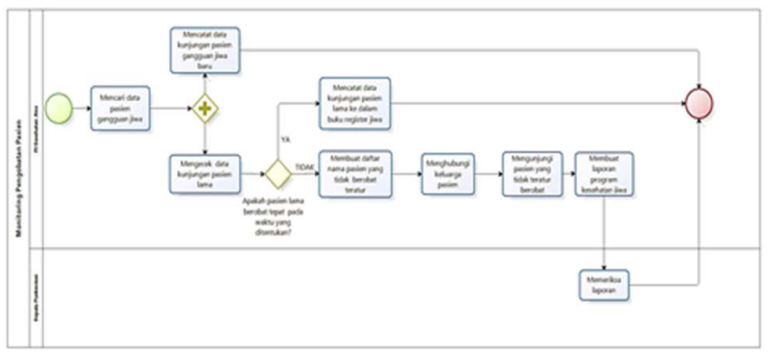

Gambar 2. BPMN Monitoring Pengobatan Pasien yang Sedang Berjalan
Berdasarkan Gambar 2 dapat dijelaskan BPMN monitoring pengobatan pasien gangguan jiwa yang sedang berjalan sebagai berikut :

1. Penanggung jawab program kesehatan jiwa mencari data kunjungan pasien gangguan jiwa di buku register poliklinik umum oleh penanggung jawab program kesehatan jiwa.

2. Penanggung jawab program kesehatan jiwa mencatat data pasien gangguan jiwa yang baru berkunjung dan mengecek data kunjungan pasien lama.

3. Jika pasien lama berkunjung ke poliklinik umum tepat pada waktu yang telah ditentukan berdasarkan kunjungan sebelumnya, maka penanggung jawab program kesehatan jiwa mencatat data kunjungan pasien tersebut pada buku register kesehatan jiwa.

4. Tetapi jika tidak, penanggung jawab program kesehatan jiwa akan mencatat nama pasien gangguan yang tidak teratur berobat dan menghubungi keluarganya untuk melakukan kunjungan ke rumah pasien tersebut.

5. Penanggung jawab program kesehatan jiwa membuat laporan tentang program kesehatan jiwa yang dapat diberikan kepada kepala puskesmas.

6. Kepala puskesmas memeriksa laporan program kesehatan jiwa

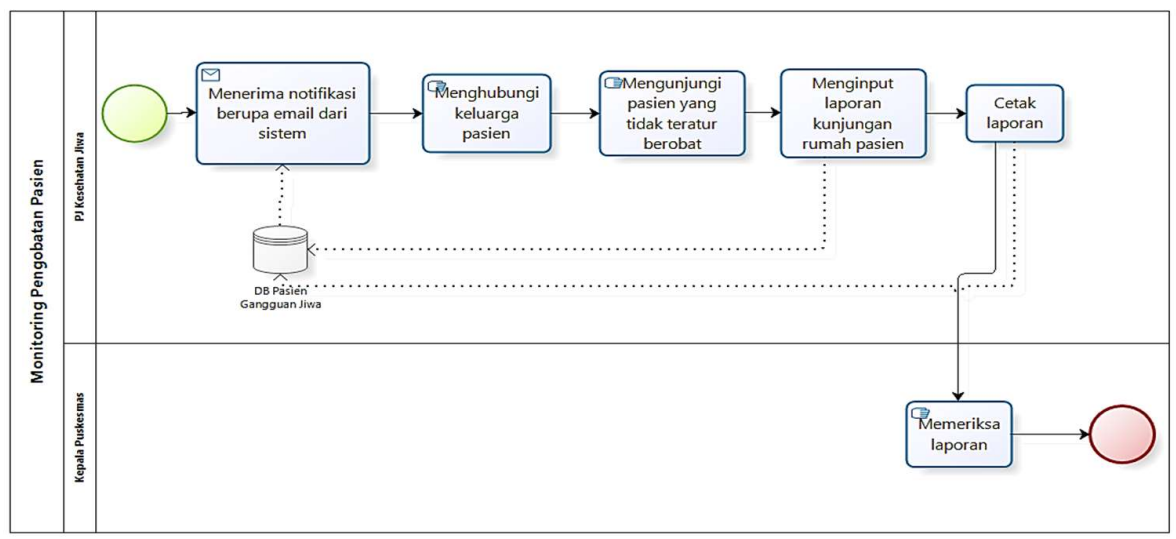

Gambar 3. BPMN Monitoring Pengobatan Pasien Gangguan Jiwa yang Diusulkan

\subsubsection{Sistem yang Diusulkan}

Berdasarkan hasil analisis terhadap system yang sedang berjalan untuk proses monitoring pengobatan pasien gangguan jiwa pada UPT Puskesmas Pasar Usang, diketahui prosesnya masih dilakukan secara manual yaitu masih mencatat di buku registrasi pasien untuk setiap kunjungan serta memeriksa satu per satu berkas terkait kunjugnan ini, hal ini tentu tidak efektif dan membutuhkan banyak waktu untuk melakukannya yang

132 Ricky Akbar berdampak terhadap waktu tunggu pada proses berikutnya, maka dapat diusulkan dengan membuat sebuah aplikasi berbasis web untuk monitoring pengobatan pasien gangguan jiwa pada UPT Puskesmas Pasar Usang, yang nantinya dapat mengatasi permasalahan yang dihadapi sebelumnya. Alur proses system yang diusulkan ini dapat dilihat pada Gambar 3. 
Berdasarkan Gambar 4 mengenai BPMN monitoring pengobatan pasien gangguan jiwa yang diusulkan dapat dijelaskan sebagai berikut :

1. Penanggung jawab program kesehatan jiwa menerima notifikasi melalui email dari sistem terkait pasien yang tidak melakukan kunjungan berobat pada waktu yang telah ditentukan pada saat kunjungan sebelumnya.

2. Setelah itu penangggung jawab program kesehatan jiwa menghubungi keluarga pasien untuk melakukan kunjungan ke rumah pasien.

3. Selanjutnya penangggung jawab program kesehatan jiwa menginputkan laporan kunjungan

\subsubsection{Use Case Diagram Aplikasi}

Use case diagram menggambarkan hubungan antara fungsional dengan aktor yang terlibat di dalam system [14]. Use case diagram pada aplikasi monitoring pengobatan pasien gangguan jiwa berbasis Web pada UPT Puskesmas Pasar Usang ini memiliki 4 aktor yaitu Admin, Petugas Piket, PJ Kesehatan Jiwa dan Petugas Apotek. Sementara itu untuk fungsionalnya terdapat delapan belas. Use Case Diagram ini dapat dilihat pada gambar 4 .

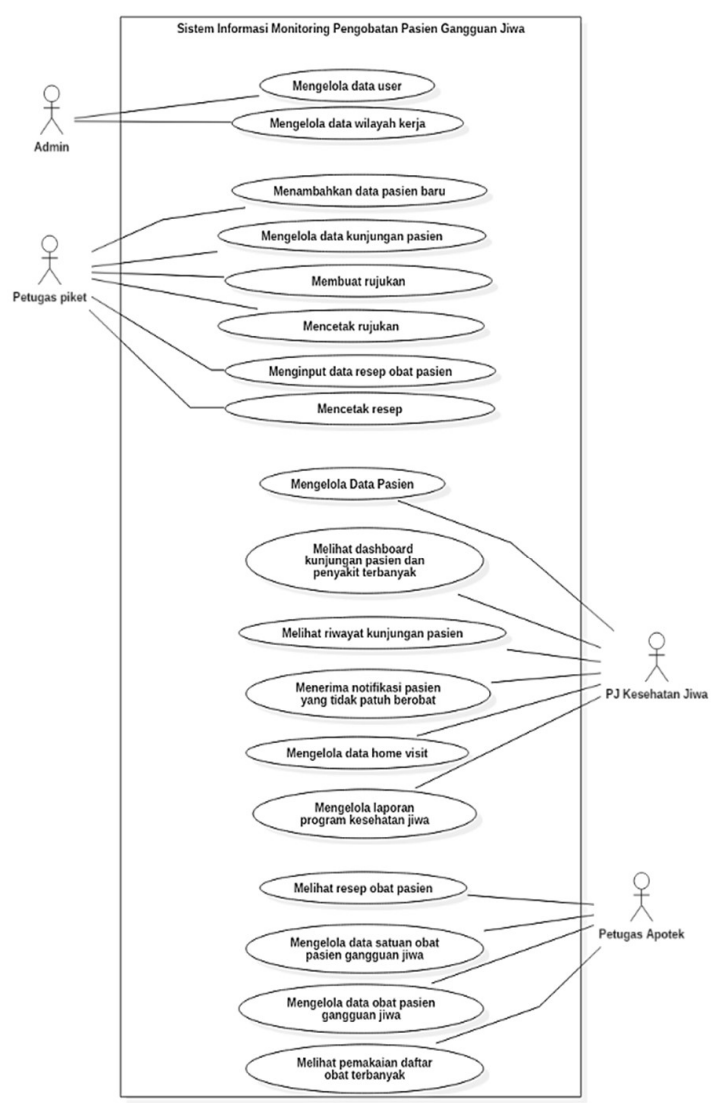

Gambar 4. Use Case Diagram Perancangan Aplikasi

\subsubsection{Use Case Scenario Aplikasi}

Use Case Scenario ini menjelaskan langkah-langkah user dalam menggunakan fungsional yang ada pada system [15]. Salah satu use case scenario yang dirancang pada apikasi ini adalah menambahkan data Home Visit. Proses use case scenario ini dapat dilihat pada tabel 1 .

https://doi.org/10.25077/TEKNOSI.v7i3.2021.130-137
Tabel 1. Use Case Scenario Menambahkan Data Home Visit

\begin{tabular}{|c|c|}
\hline Use Case Name & Menambahkan Data Home Visit \\
\hline $\begin{array}{l}\text { Participating } \\
\text { Actors }\end{array}$ & Penanggung jawab kesehatan jiwa \\
\hline Entry Condition & Aktor telah login ke aplikasi \\
\hline Flow Condition & $\begin{array}{l}\text { 1. Aktor telah membuka menu home } \\
\text { visit } \\
\text { 2. Sistem menampilkan data } \\
\text { home visit } \\
\text { 3. Aktor memilih button tambah data } \\
\text { 4. Sistem menampilkan form } \\
\text { input (tambah) data home visit } \\
\text { 5. Aktor menginputkan data home visit } \\
\text { 6. Aktor menekan button simpan } \\
\text { 7. Sistem menyimpan data yang } \\
\text { telah diinputkan ke dalam } \\
\text { database }\end{array}$ \\
\hline $\begin{array}{l}\text { Alternative } \\
\text { Scenario }\end{array}$ & $\begin{array}{l}\text { 5. Aktor menginputkan data home visit } \\
\text { yang salah } \\
\text { 6. Aktor menekan button selesai } \\
\text { 7. Sistem menampilkan } \\
\text { notifikasi kesalahan }\end{array}$ \\
\hline Exit Condition & $\begin{array}{l}\text { Sistem menyimpan data home visit yang } \\
\text { telah diinputkan }\end{array}$ \\
\hline
\end{tabular}

\subsection{Perancangan Sistem}

Perancangan sistem ini meliputi perancangan database, arsitektur aplikasi dan user interface.

\subsubsection{Perancangan Database}

Perancangan database dilakukan dengan cara menyusun struktur database berdasarkan entitas yang saling berhubungan antara satu dengan yang lainnya. Perancangan database digambarkan melalui ERD (Entity Relational Diagram) yang merepresentasikan model data pada sistem. Pada aplikasi monitoring pengobatan pasien gangguan jiwa pada UPT Puskesmas Pasar Usang menggunakan 15 tabel yang saling berelasi satu dengan yang lainnya. Rancangan ERD aplikasi ini dapat dilihat pada Gambar 5.

\subsubsection{Arsitektur Aplikasi}

Arsitektur aplikasi yang digunakan dalam membangun aplikasi ini yaitu arsitektur MVC (Model View Controller) dengan menggunakan metode OOP (Object Oriented Programming) dan framework Laravel. Arsitektur ini dirancang untuk menggambarkan komponen teknologi yang saling berintegrasi dalam menerapkan system yang dibangun. Arsitektur aplikasi ini dapat dilihat pada Gambar 6.

Berdasarkan Gambar 6, arsitektur ini memisahkan antara data (model), tampilan (view), dan pemanggil keduanya dengan controller. User akan melakukan permintaan kepada sistem, lalu routing akan mengarahkan request kepada controller yang dituju. Setelah itu controller akan menjalankan method nya untuk menangani request dan mengambil data ke model. Kemudian model akan mengambil data yang sesuai dengan permintaan user ke dalam database. Data yang telah diambil dari database ditampilkan oleh controller ke view untuk dapat dilihat oleh user. 


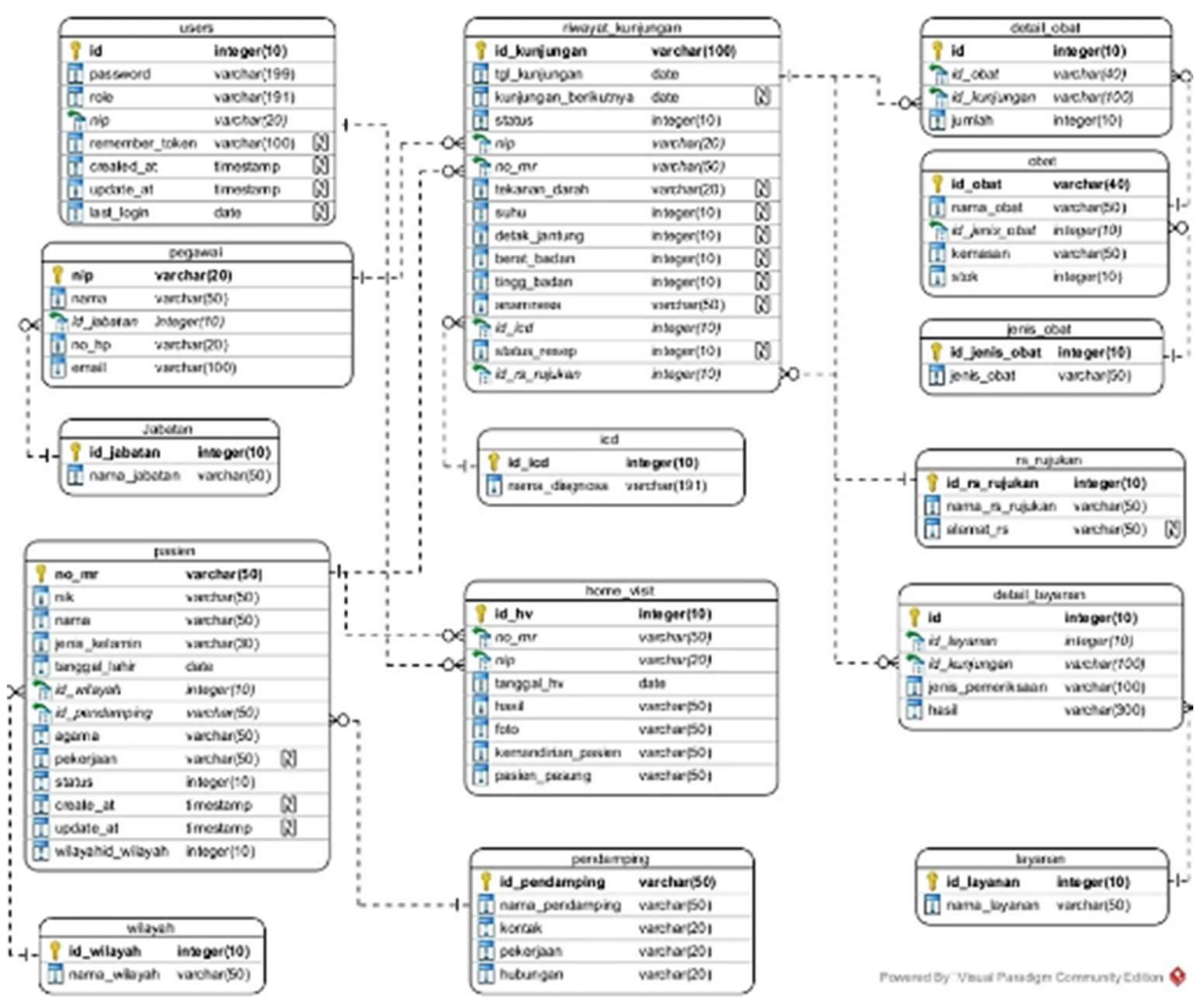

Gambar 5. Rancangan ERD Aplikasi Monitoring Pengobatan Pasien Gangguan Jiwa

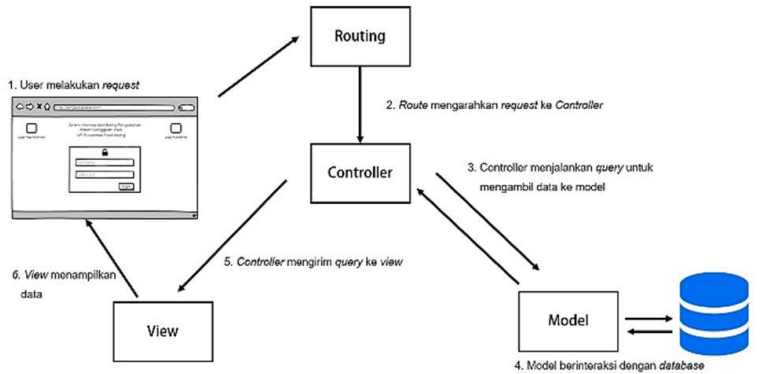

Gambar 6. Arsitektur Aplikasi

\subsubsection{Perancangan User Interface}

Perancangan antarmuka adalah sebuah proses yang dilakukan dalam membangun tampilan grafis dari sebuah aplikasi dengan tujuan dapat membantu pengguna ketika menggunakan aplikasi tersebut [14]. Perancangan antarmuka biasanya terdiri dari tombol yang di klik oleh pengguna, teks yang dapat dibaca oleh pengguna, maupun bidang entri tempat pengguna memasukkan datanya. Tampilan satu antarmuka untuk form Home Visit yang dapat dilihat pada Gambar 7.

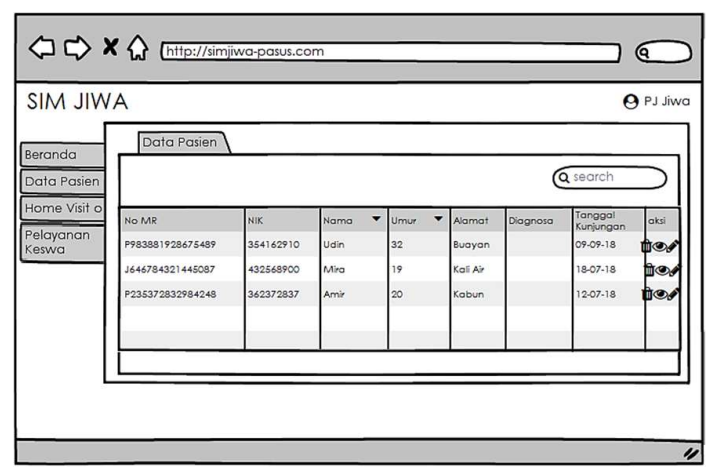

Gambar 7. User Interface Tampilan Home Visit

\section{PEMBAHASAN}

Dalam menerapkan aplikasi monitoring pengobatan pasien gangguan jiwa pada UPT Puskesmas Pasar Usang, dilakukan tahapan pengkodean menggunakan bahasa pemrograman Hypertext Processor (PHP) dan framework Laravel. Sedangkan database yang digunakan untuk mengelola data yang disimpan adalah MySQL. Tahapan implementasi sistem dilakukan berdasarkan perancangan yang telah dilakukan pada bagian sebelumnya dan proses pengujian dilakukan dengan melihat kesesuaian aplikasi yang dibangun dengan alur proses monitoring pengobatan pasien gangguan jiwa pada UPT Puskesmas Pasar Usang.

\subsection{Implementasi Antar Muka Aplikasi}

Pada bagian ini dijelaskan antarmuka aplikasi monitoring pengobatan pasien gangguan jiwa pada UPT Puskesmas Pasar Usang yang sedang dibangun. Antarmuka aplikasi terdiri dari 
beberapa halaman yang bisa diakses berdasarkan role akses yang telah ditentukan. Berikut salah satu tampilan antarmuka aplikasi yaitu halaman beranda penanggung jawab program kesehatan jiwa pada Gambar 8.

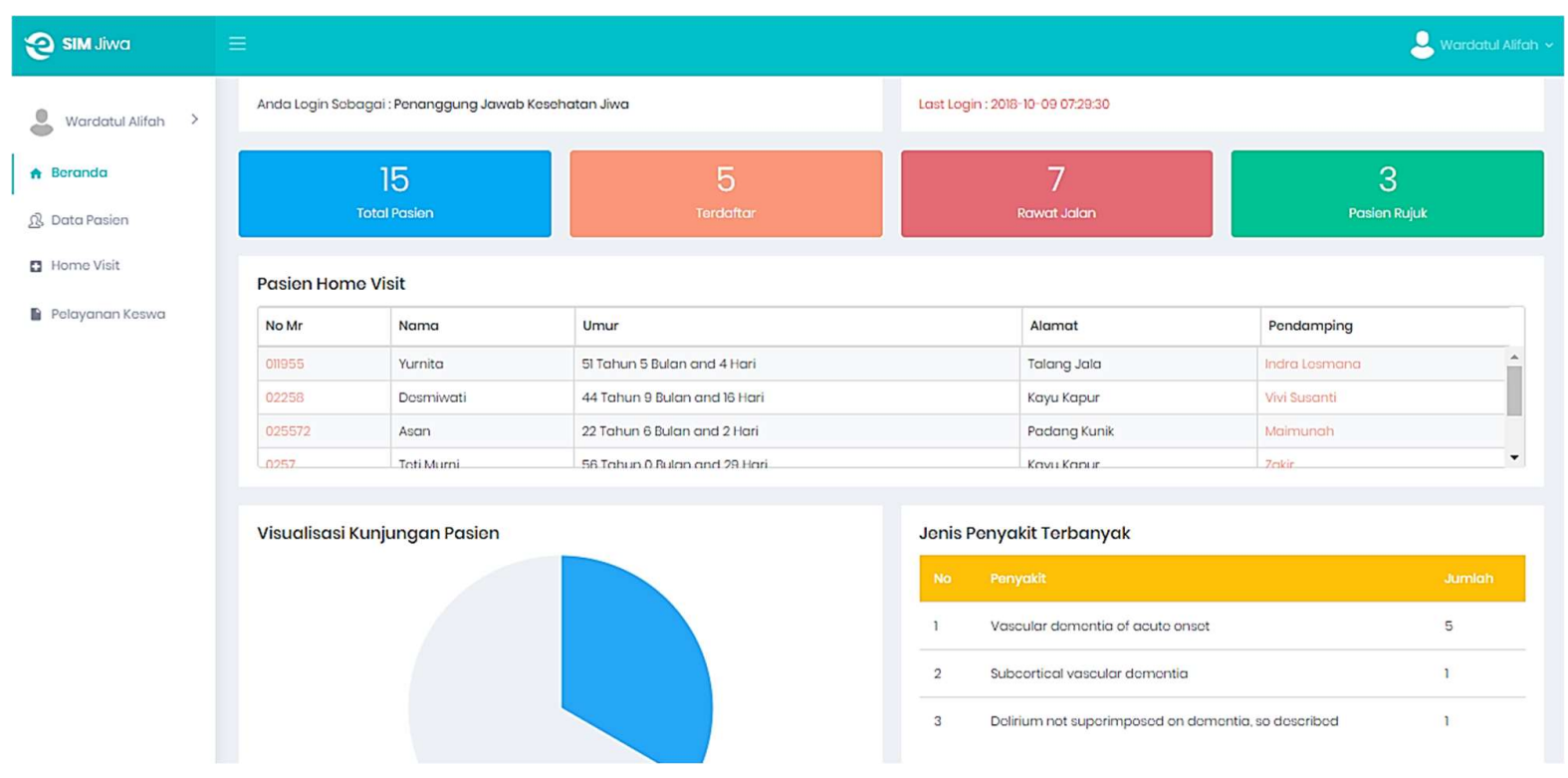

Gambar 8. Antarmuka Halaman Beranda Penanggung Jawab Program Kesehatan Jiwa

\subsection{Pengujian Sistem}

Pengujian sistem merupakan proses yang dilakukan untuk menguji apakah aplikasi yang telah dibangun sesuai dengan perancangan sistem yang telah dibuat. Pengujian sistem dilakukan dengan metode blackbox testing. Pengujian ini dilakukan oleh admin, petugas piket, penanggung jawab program kesehatan jiwa dan petugas apotek UPT Puskesmas Pasar Usang. Salah satu pengujian yang dilakukan yaitu pengujian notifikasi email kepada penanggung jawab program kesehatan jiwa. Pada pengujian ini dilakukan input data tanggal kunjungan pasien berikutnya. Hasil pengujian notifikasi email penanggung jawab program kesehatan jiwa dapat dilihat pada Tabel 2.

Pengujian dilakukan dengan memasukkan tanggal kunjungan berobat pasien berikutnya pada saat mengisi data kunjungan berobat. Apabila pasien tidak kembali berobat pada tanggal yang telah ditentukan maka system mengirimkan notifikasi melalui email kepada penanggung jawab program kesehatan jiwa. Tampilan Halaman pengujian yang telah dilakukan dapat dilihat pada gambar 9 dan gambar 10
Tabel 2. Pengujian Notifikasi Email Penanggung Jawab Program Kesehatan Jiwa

\begin{tabular}{ll}
\hline \multicolumn{2}{l}{ Kasus dan Hasil Uji (Benar) } \\
\hline Data masukan & Tanggal kunjungan pasien berikutnya \\
\hline Yang diharapkan & Sistem mengirimkan notifikasi ke email \\
& penanggung jawab program kesehatan \\
& jiwa apabila pasien tidak berkunjung \\
& sesuai dengan tanggal yang telah \\
& ditentukan \\
\hline Pengamatan & Penanggung jawab program kesehatan \\
& jiwa menerima email terkait pasien yang \\
& akan dilakukan home visit \\
\hline Hasil & Sesuai \\
\hline
\end{tabular}

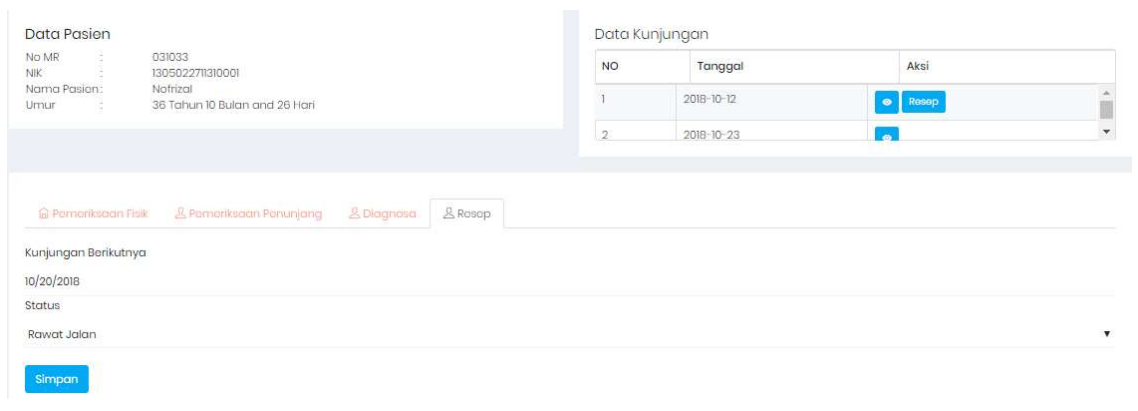

Gambar 9. Input Pengujian Notifikasi Email Penanggung Jawab Program Kesehatan Jiwa

Untuk melakukan pembuktian bahwa proses menambahkan resep sesuai dengan keinginan, maka pengujian dilanjutkan dengan 
mengakses langsung ke database dan melakukan query select dengan field id pada tabel riwayat_kunjungan. Pembuktian dengan query database dapat dilihat pada gambar 11.

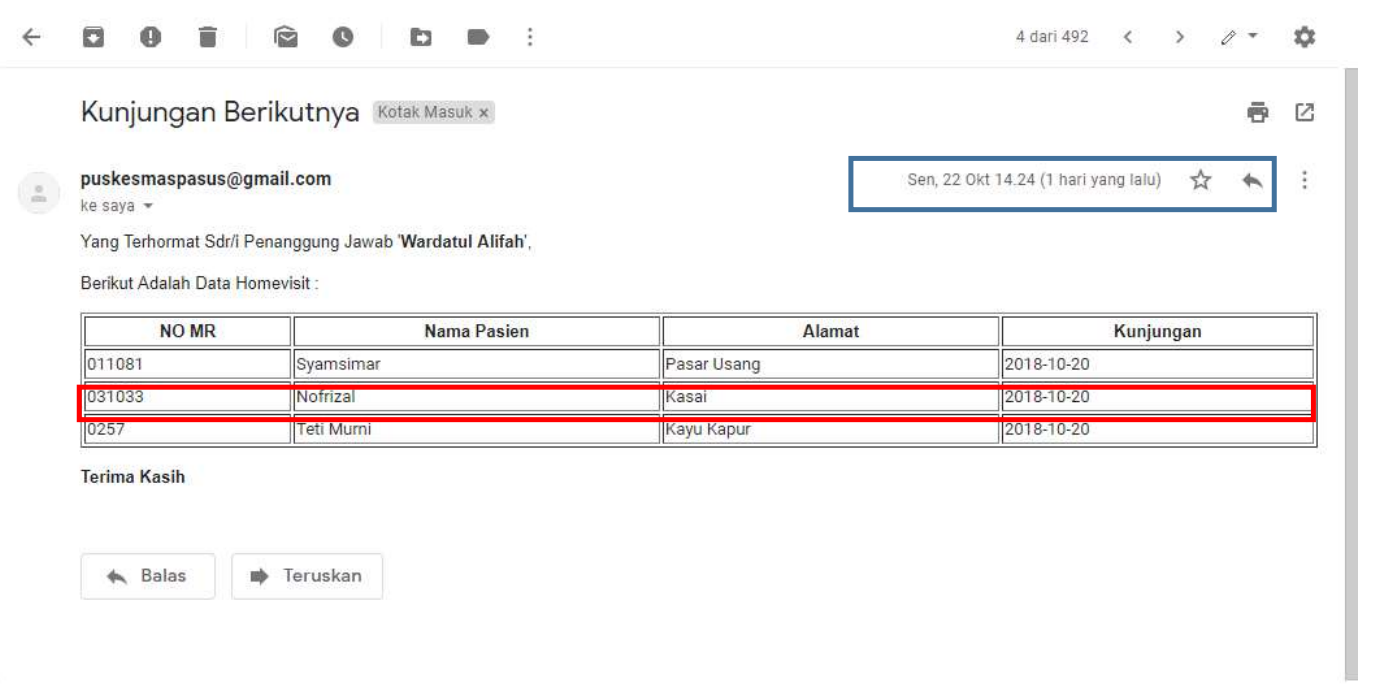

Gambar 10. Output Pengujian notifikasi email penanggung jawab program kesehatan jiwa

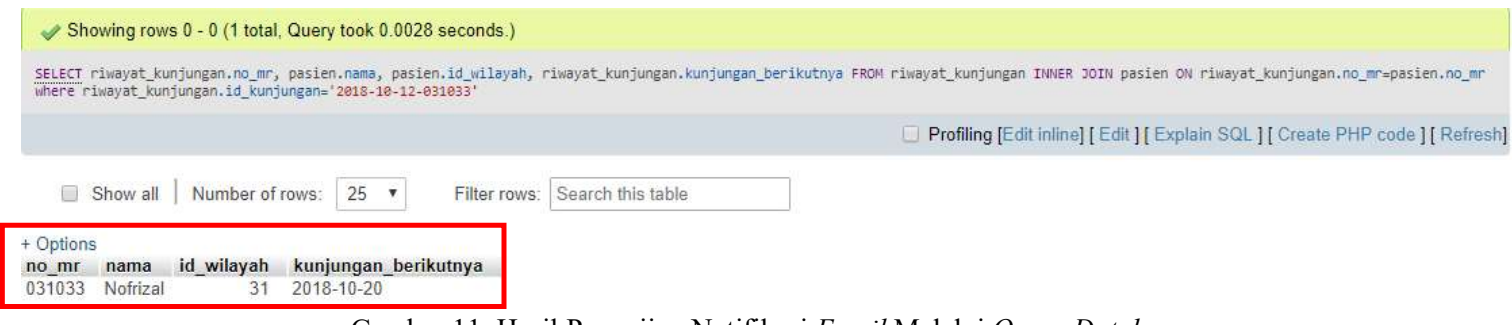

Gambar 11. Hasil Pengujian Notifikasi Email Melalui Query Database

\section{KESIMPULAN}

Aplikasi sistem informasi monitoring pengobatan pasien gangguan jiwa pada UPT Puskesmas Pasar Usang telah berhasil dibangun dan diterapkan menggunakan metode waterfall. Tahapan yang dilakukan dalam metode waterfall yaitu tahapan analysis, design, coding dan testing. Pada tahapan analysis didapatkan data dan informasi tentang alur proses bisnis monitoring pengobatan pasien gangguan jiwa pada UPT Puskesmas Pasar Usang yang digambarkan menggunakan tool Business Process Modelling Notation (BPMN) dan kebutuhan fungsional yang digambarkan dengan pemodelan UML. Sementara itu pada tahap design (perancangan) dilakukan perancangan database yang dimodelkan dengan Entity Relationship Diagram (ERD), perancangan antar mukan dan arsitektur aplikasi. Kemudian tahapan coding menggunakan bahasa pemrograman PHP dan framework Laravel 5.5. Tahapan ini dilakukan untuk untuk mengimplementasikan rancangan dari fungsional serta interface yang telah dirancang sebelumnya. Terakhir tahapan pengujian yang dilakukan dengan menggunakan metode blackbox testing. Dari hasil pengujian yang telah dilakukan, diperloah kesimpulan bahwa ketersediaan fungsional pada aplikasi yang telah dibangun sesuai dengan perancangan yang telah dilakukan sebelumnya.

\section{DAFTAR PUSTAKA}

[1] Peraturan Bupati Padang Pariaman No.21 tahun 2018 Tentang Pembentukan Unit Pelaksana Teknis Daerah Pusat Kesehatan Masyarakat.

[2] DepKes, R. I. (2010). Profil Kesehatan Indonesia

[3] Khariza, H. A. (2015). Program Jaminan Kesehatan Nasional: Studi Deskriptif Tentang Faktor-Faktor Yang Dapat Mempengaruhi Keberhasilan Implementasi Program Jaminan Kesehatan Nasional Di Rumah Sakit Jiwa Menur Surabaya. Jurnal Kebijakan dan Manajemen Publik, 3(1), 1-7

[4] Purwanto, A. (2010). Faktor-faktor yang berhubungan dengan kekambuhan pasien skizofrenia di Rumah Sakit Jiwa Daerah Surakarta (Doctoral dissertation, Universitas Muhammadiyah Surakarta)

[5] Puskesmas, Pasar Usang. 2018. Laporan Bulanan Program Kesehatan Jiwa. Padang Pariaman

[6] Krisantoso, Gilbert (2015). Penerapan Business Process Modeling Notation (BPMN) untuk Memodelkan Kebutuhan Sistem Proses Penyuntingan Tulisan Pada Website Jurnal Jtriste. Seminar Nasional Forum Dosen Indonesia. ISBI Bandung 
[7] Mulyani, Sri. (2017). Sistem Informasi Manajemen Rumah Sakit: Analisis dan Perancangan. Abdi Sistematika

[8] Nugroho, Adi. (2010). Rekayasa Perangkat Lunak Berorientasi Objek dengan Metode USDP. Andi.

[9] Stone, A. Redmer, T. (2006). The Case Study Approach to Scenario Plannin. Journal of Practical Consulting, 1(1), pp. $7-18$

[10] Syafitri, Marliza. (2017). Pembangunan Sistem Informasi Rekam Medis Pasien Berbasis Web Dengan Fitur Mobile Pada Puskesmas Kecamatan X Koto Singkarak. Padang

[11] Akbar. R, Silvana. M, Zikri. A. 2019. Perancangan Model Bisnis Pembayaran Non Tunai untuk Pengelolaan Transaksi Jasa Laundry Pada Tiara Laundry Padang. Jurnal Teknosi Vol. 05 No. 032019.

[12] Sommerville. 2011. Software Engineering Ninth Edition, Boston: Person Education

[13] Iskandaria (2012), blackbox (blackbox testing), metode pengujian perangkat lunak yang berfokus pada sisi fungsionalitas

[14] Yorizka. AO, Putra. HY, Akbar. F. 2021. Implementasi Sistem Automasi Berbasis Web Pada Proses Check In dan Check Out Asrama Universitas Andalas. Jurnal Teknosi Vol 07 No. 022021.

[15] Akbar. R, Silvana. M, Alizar AF. 2019. Perancangan Aplikasi Pembayaran Non Tunai Untuk Pengelolaan Bisnis Pencucian Mobil Dengan Memanfaatkan Teknologi QR Code (Studi Kasus : Oto Pro Car Wash \& Detailing Padang). Seminar Nasional Sains dan Teknologi (Semnastek). UMJ Jakarta. 